\title{
Expression and Flavinylation of Arthrobacter oxydans 6-Hydroxy-D-nicotine Oxidase in Bacillus subtilis
}

\author{
By RODERICH BRANDSCH ${ }^{1}$ AND LARS HEDERSTEDT ${ }^{2 *}$ \\ ${ }^{1}$ Biochemisches Institut der Universität, Hermann-Herder Strasse 7, D-7800 Freiburg im \\ Breisgau, FRG \\ ${ }^{2}$ Department of Microbiology, University of Lund, Sölvegatan 21, S-223 62 Lund, Sweden
}

(Received 17 October 1988; revised 24 January 1989; accepted 30 January 1989)

\begin{abstract}
6-Hydroxy-D-nicotine oxidase (6-HDNO) of Arthrobacter oxydans, an enzyme inducible by DLnicotine, contains FAD covalently bound via an $8 \alpha-\mathrm{N}(3)$ His linkage. Expression of the gene encoding 6-HDNO and flavinylation of the protein were studied in Bacillus subtilis. In this heterologous system the following findings were made. 1. An enzymically active covalently flavinylated 6-HDNO of normal size can be expressed in $B$. subtilis. 2. The natural promoter of the 6-HDNO gene appeared inefficient in $B$. subtilis. The $B$. subtilis sdh promoter, when inserted upstream of the $A$. oxydans promoter, increased 6-HDNO expression $>50$-fold. 3 . Expression of the 6-HDNO gene from plasmids in $B$. subtilis was, independently of the promoter construct used, stimulated more than fivefold by DL-nicotine in the growth medium. It is concluded that flavinylation of 6-HDNO is possibly autocatalytic and mediated by factors generally found in bacterial cells.
\end{abstract}

\section{INTRODUCTION}

About two dozen different enzymes are known to contain a flavin covalently attached to a His, Tyr or Cys residue (Singer \& McIntire, 1984). The mechanism(s) by which these covalent bonds are formed in cells is not known. Autocatalysis as well as a requirement for specific factor(s), not present in the final flavoprotein, have been proposed for the process (Decker, 1982). FAD linked via its $8 \alpha$-carbon to $\mathrm{N}-3$ of $\mathrm{His}$ was first discovered in succinate dehydrogenase (SDH) (Salach et al., 1972). The same type of covalently bound FAD is present in 6-hydroxy-D-nicotine oxidase (6-HDNO; EC 1.5.3.6) from Arthrobacter oxydans (Möhler et al., 1972). 6-HDNO is a $48 \mathrm{kDa}$ monomeric enzyme functioning in the nicotine degradative pathway of this bacterium (Brühmüller et al., 1972). It is encoded on a large catabolic plasmid and enzyme synthesis is induced by DL-nicotine (Brandsch et al., 1986; Gloger \& Decker, 1969).

$\mathrm{SDH}$, the analogous fumarate reductase, and 6-HDNO are at present the only proteins with $8 \alpha-\mathrm{N}(3)$ His FAD for which the structural gene has been isolated and sequenced (Wood et al., 1984; Phillips et al., 1987; Cole, 1982; Brandsch et al., 1987 b). With the cloned gene available, new approaches can be used to elucidate why the prosthetic group in particular flavoenzymes is covalently bound and how the bond is formed (cf. Cecchini et al., 1988). One approach to these problems is to express the flavoprotein in a heterologous system. Bacillus subtilis SDH expressed from the cloned sdh operon in Escherichia coli lacks covalently bound flavin despite the fact that $E$. coli $\mathrm{SDH}$ in the same cell is flavinylated (Hederstedt et al., 1987). The $B$. subtilis apoprotein synthesized in $E$. coli is correctly processed at the $\mathrm{N}$-terminus and the cloned $s d h$ operon encodes functional SDH when reintroduced into $B$. subtilis. These previous results indicate that a cellspecific factor is required or that in $E$. coli the flavinylation of the heterologous polypeptide is

\footnotetext{
Abbreviations: Ap, ampicillin; Cm, chloramphenicol; 6-HDNO, 6-hydroxy-D-nicotine oxidase; Km, kanamycin; PEP, phosphoenolpyruvate; SDH, succinate dehydrogenase.
} 
blocked. In contrast to the $B$. subtilis $\mathrm{SDH}, A$. oxydans 6-DHNO is flavinylated when expressed in $E$. coli, both in vivo and in a cell-free system (Brandsch \& Bichler, 1985, 1986). This discrepancy made it interesting to determine whether FAD can be covalently bound to the 6-HDNO polypeptide in B. subtilis.

Bacillus and Arthrobacter species are of great industrial importance, e.g. as producers of enzymes and antibiotics. The two genera are evolutionarily only distantly related (Woese, 1987) but comprise Gram-positive aerobic bacteria commonly found in the soil. Comparatively little is known about gene organization and control in Arthrobacter species. These aspects were additional reasons to determine whether the 6-HDNO gene could be expressed and be regulated by nicotine in $B$. subtilis.

\section{METHODS}

Bacterial strains and plasmids. The strain of $A$. oxydans used was described by Eberwein et al. (1961).

B. subtilis $3 \mathrm{G} 18$ (trpC2 ade met) was obtained from G. Venema, University of Groningen, the Netherlands. Plasmids pDB121 (Brandsch et al., 1986) and pDB222 (Brandsch et al., 1987a) are both Apr and contain the $A$. oxydans 6-HDNO gene under the control of its natural promoter and the $E$. coli tac promoter, respectively. These plasmids were propagated in E. coli $\mathrm{HB} 101\left(\mathrm{~F}^{-}\right.$hsdS20 supE44 ara- 14 galK2 lacY1 proA2 rpsL20 xyl-5 mtl-1 recA13) (Boyer \& Roulland-Dussoix, 1969). B. subtilis plasmids pUB110 $\left(\mathrm{K} \mathrm{m}^{r}\right)$ (Gryczan et al., 1978) and pSDP4 $\left(\mathrm{Km}^{\mathrm{r}} \mathrm{Cm}^{\mathrm{r}}\right)$ (Melin et al., 1987) have been described before; pHB2 $\left(\mathrm{Km}^{\mathrm{r}}\right)$ and $\mathrm{pHB} 41\left(\mathrm{Km}^{r}\right)$ were constructed during this work.

General genetic techniques. Digestion of DNA with restriction endonucleases, agarose gel electrophoresis and ligation with T4 DNA ligase were done according to standard methods (Berger \& Kimmel, 1987). DNA fragments separated in agarose gels were isolated by the use of Geneclean after the agarose had been dissolved in $4 \mathrm{M}-\mathrm{NaI}$. B. subtilis plasmids were purified as described by Ish-Horowicz \& Burke (1981) except that the cells were treated with $0.2 \mathrm{mg}$ lysozyme $\mathrm{ml}^{-1}$ at $37^{\circ} \mathrm{C}$ for $30 \mathrm{~min}$ before alkaline sodium dodecyl sulphate (SDS) was added. Competent $B$. subtilis was prepared as described by Arwert \& Venema (1973). Transformants were selected on plates of Tryptose Blood Agar Base (Difco) containing $5 \mu \mathrm{g} \mathrm{Km}$ or $\mathrm{Cm} \mathrm{ml}^{-1}$.

Construction of $p H B 2$ and $p H B 41$. The 6-HDNO gene from $A$. oxydans pAO1 was originally cloned in pBR 322 as a $2.8 \mathrm{kbp} \mathrm{EcoRI-HindIII} \mathrm{fragment} \mathrm{(Brandsch} \mathrm{et} \mathrm{al.,} \mathrm{1986).} \mathrm{This} \mathrm{recombinant} \mathrm{plasmid,} \mathrm{designated} \mathrm{pDB121,} \mathrm{and}$ the B. subtilis cloning vector pUB 110 were both digested with EcoRI and BamHI. The $3.1 \mathrm{kbp}$ fragment of pDB121 and the $3.7 \mathrm{kbp}$ fragment of pUB110 were isolated from agarose gels and ligated. $B$. subtilis $3 \mathrm{G} 18$ was then transformed with the ligation mix and $\mathrm{Km}^{\mathrm{r}}$ selected. Plasmid pHB2 (Fig. 1) was isolated from one of the transformants.

The plasmid pHB41 was constructed from plasmids pHB2 and pSDP4, a derivative of pPL603 (Williams et al., 1981 ) in which the cat -86 gene is transcribed from the $B$. subtilis sdh promoter. The vector part of pSDP4 including the $s d h$ promoter, but only the latter half of $c a t-86$, was isolated after removal of the $0.52 \mathrm{kbp}$ PstI-HindIII DNA fragment. The removed fragment was replaced by the $2 \cdot 2 \mathrm{kbp}$ PstI-HindIII fragment of pHB2. The resulting plasmid $\mathrm{pBH} 41$, containing the $s d h$ promoter in front of the 6-HDNO gene (Fig. 1), was isolated from one B. subtilis $3 \mathrm{G} 18 \mathrm{Km}^{r} \mathrm{Cm}^{\mathrm{s}}$ transformant.

Preparation of soluble cell extract. The bacteria were grown aerobically overnight at $30^{\circ} \mathrm{C}$ in yeast-tryptone medium (YT; Berger \& Kimmel, 1987) with and without added DL-nicotine $(0 \cdot 1 \%, \mathrm{v} / \mathrm{v})$. The growth medium for plasmid-containing cells was further supplemented with $100 \mu \mathrm{g}$ ampicillin $\mathrm{ml}^{-1}$ or $5 \mu \mathrm{g}$ kanamycin $\mathrm{ml}^{-1}$, as appropriate. Cells were harvested by centrifugation at $4^{\circ} \mathrm{C}$, washed once with cold $0.1 \mathrm{M}$-sodium phosphate buffer $\mathrm{pH} 7.5$ and lysed in the same buffer by sonication. B. subtilis cells were incubated at $20^{\circ} \mathrm{C}$ for $10 \mathrm{~min}$ in buffer containing $0.1 \mathrm{mg}$ lysozyme $\mathrm{ml}^{-1}$ before sonication. The lysate was centrifuged at $12000 \mathrm{~g}$ for $10 \mathrm{~min}$ at $4{ }^{\circ} \mathrm{C}$ and the resulting supernatant was used as the soluble cell fraction.

Labelling with radioactive flavin. In vivo labelling with $20 \mu \mathrm{Ci}(740 \mathrm{kBq}) \mathrm{D}-\left[2{ }^{-14} \mathrm{C}\right]$ riboflavin $\mathrm{I}^{-1}$ in the growth medium has been described before (Hederstedt, 1983). For in vitro labelling with flavin, the cell extract was incubated with $10 \mu \mathrm{M}-\left[{ }^{14} \mathrm{C}\right] \mathrm{FAD}$ and $8 \mathrm{mM}$-phosphoenolpyruvate (PEP) at $30^{\circ} \mathrm{C}$ for $60 \mathrm{~min}$.

Analytical methods. 6-HDNO activity was measured photometrically at $30^{\circ} \mathrm{C}$ as described by Decker \& Bleeg (1965). Chloramphenicol acetyltransferase was assayed as described by Shaw (1975). SDS-polyacrylamide gel electrophoresis (SDS-PAGE) was done by the method of Laemmli (1970). Gels for autoradiography were treated with Amplify before they were exposed to X-ray film. Identification of 6-HDNO antigen by SDS-PAGE followed by immunoblotting was performed as before (Brandsch et al., 1987a). Protein was determined by the Lowry method with serum albumin as the standard. 

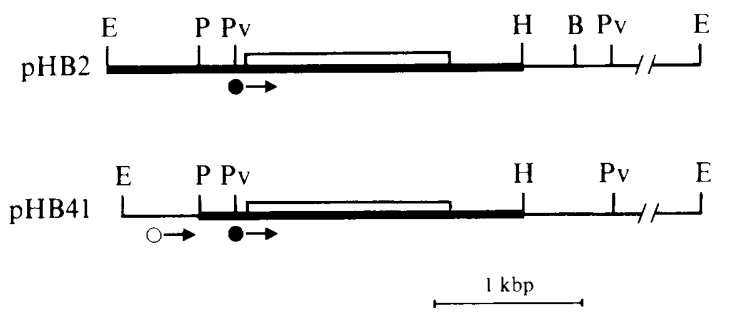

Fig. 1. Physical map of pHB2 and pHB41. Both plasmids are pUB110 derivatives. The fragment corresponding to $A$. oxydans DNA is indicated by a thicker line and the open reading frame of the 6-HDNO gene is marked by a box. The filled and open dots indicate the location of the $A$. oxydans natural promoter for the 6-HDNO gene and the $B$. subtilis sdh promoter respectively. Arrows show direction of transcription. Selected endonuclease restriction sites are indicated: B, Bam HI; E, Eco RI; H, HindIII; P, PstI ; Pv, PvuII.

Materials. Restriction enzymes and T4 DNA ligase were obtained from Boehringer Mannheim; $\mathrm{D}-\left[2-{ }^{14} \mathrm{C}\right]$ riboflavin $\left(46 \mathrm{Ci} \mathrm{mol}^{-1} ; 1702 \mathrm{GBq} \mathrm{mol}{ }^{-1}\right)$ and Amplify were from Amersham; $\left[{ }^{14} \mathrm{C}\right] \mathrm{FAD}$ was synthesized in vitro from $\mathrm{D}-\left[2{ }^{-14} \mathrm{C}\right]$ riboflavin (Brandsch \& Bichler, 1987); DL-nicotine and 6-hydroxy-D-nicotine were obtained as described previously (Decker et al., 1961 ; Gloger \& Decker, 1969). Geneclean was purchased as a kit from BIO 101 Inc. X-ray film was XR from Fuji.

\section{RESULTS AND DISCUSSION}

\section{Expression of 6-HDNO activity in B. subtilis}

To study expression of $A$. oxydans 6-HDNO in B. subtilis, the structural gene with flanking DNA was transferred to $B$. subtilis plasmid vectors. Two plasmids, both based on pUB110, were constructed as described in Methods. The first plasmid, pHB2, contains the 6-HDNO gene with its natural promoter (Fig. 1). The second construct, pHB41, has the B. subtilis sdh promoter region placed upstream and in tandem with the natural promoter of the 6-HDNO gene (Fig. 1).

Soluble cell extracts of $B$. subtilis harbouring pHB2 and pHB41, but not of cells containing pUB110 or pSDP4, showed 6-hydroxynicotine oxidase activity with specificity for the D-enantiomer. Extracts prepared from cells in the stationary phase of growth had higher specific enzyme activities than those of exponentially growing bacteria. Stationary phase cells were therefore used throughout this work.

Plasmid pHB41, with the $s d h$ promoter placed in tandem with and in front of the natural promoter, resulted in $>50$-fold higher 6 -HDNO activity compared to pHB2 (Table 1). This suggests that transcription, rather than translation, is limiting the expression of the protein from $\mathrm{pHB} 2$, assuming that the copy number is similar for $\mathrm{pHB} 41$ and $\mathrm{pHB} 2$. The promoter sequence of the $A$. oxydans 6-HDNO gene (Brandsch et al., 1987 b) and the consensus promoter sequence recognized by the major (sigma-43) B. subtilis RNA polymerase holoenzyme (Doi \& Wang, 1986) are identical in the -35 region but show 3 mismatches out of 7 bases in the -10 region. The potential ribosome-binding sequence of the mRNA for the 6-HDNO gene and the 3'-end of the $B$. subtilis $16 \mathrm{~S}$ rRNA has a calculated (Tinoco et al., 1973) free energy of interaction of -58 $\mathrm{kJ} \mathrm{mol}^{-1}\left(-14 \mathrm{kcal} \mathrm{mol}^{-1}\right)$. This strength of interaction and also the $6 \mathrm{bp}$ spacing between the ribosome-binding sequence and the TTG translational start codon are features commonly found for B. subtilis genes (Hager \& Rabinowitz, 1985).

DL-Nicotine induces 6-HDNO in stationary-phase $A$. oxydans cells. The difference in activity between induced and non-induced bacteria is about 2000-fold. Expression of 6-HDNO activity in $B$. subtilis containing pHB2 or pHB41 was also stimulated by DL-nicotine (Table 1). In contrast and as observed before (Brandsch et al., 1986), nicotine had no effect on the expression of 6-HDNO activity in $E$. coli harbouring pBD121, although this plasmid contains the same 
Table 1. Specific 6-HDNO activity in soluble cell extracts of different bacterial strains grown in the presence or absence of $0 \cdot 1 \%(v / v)$ DL-nicotine

Extracts from cells in stationary growth phase were used: all strains showed the highest 6-HDNO activity in this growth phase. Results are means \pm standard deviation (number of determinations).

\begin{tabular}{|c|c|c|}
\hline & \multicolumn{2}{|c|}{ 6-HDNO activity [mU (mg protein $\left.)^{-1}\right]$} \\
\hline Strain & $\begin{array}{l}\text { Without } \\
\text { nicotine }\end{array}$ & $\begin{array}{c}\text { With } \\
\text { nicotine }\end{array}$ \\
\hline A. oxydans $(\mathrm{pAO} 1)$ & $0 \cdot 1^{*}$ & $200 \pm 12 \cdot 7(10)$ \\
\hline E. coli $\mathrm{HB} 101(\mathrm{pDB} 121)$ & $13 \pm 1 \cdot 5(10)$ & $14 \pm 2(10)$ \\
\hline B. subtilis $3 \mathrm{G} 18(\mathrm{pHB} 2)$ & $0 \cdot 1^{*}$ & $0.4 \pm 0.1$ \\
\hline B. subtilis $3 \mathrm{G} 18(\mathrm{pHB} 41)$ & $6.5 \pm 1.8(3)$ & $40 \pm 3.8(3)$ \\
\hline
\end{tabular}

* At the limit of detection.

Table 2. Enhancement of 6-HDNO activity in soluble cell extracts of $B$. subtilis $3 G 18(p H B 4 I)$ by incubation with $F A D$ and PEP

The same extracts of $B$. subtilis 3G18(pHB41) grown in the absence or presence of nicotine, and which showed 4 and $37 \mathrm{mU}(\mathrm{mg} \text { protein })^{-1}$ of 6-HDNO activity, respectively, were used several times in activation assays with FAD and PEP.

\begin{tabular}{|c|c|c|}
\hline \multirow[b]{2}{*}{ Extract } & \multicolumn{2}{|c|}{ 6-HDNO activity [mU (mg protein $\left.)^{-1}\right]$} \\
\hline & +FAD & $+\mathrm{FAD}+\mathrm{PEP}^{*}$ \\
\hline Without nicotine & 4 & $12 \pm 2(5)$ \\
\hline With nicotine & 37 & $55 \pm 4(5)$ \\
\hline
\end{tabular}

A. oxydans DNA fragment as pHB2. How nicotine can influence the expression of 6-HDNO in B. subtilis is not known. However, the effect was not specific since the expression of chloramphenicol acetyltransferase from the cat-86 gene transcribed from the $s d h$ promoter in pSDP4 could also be stimulated (about six-fold) by nicotine.

\section{Flavinylation of 6-HDNO}

B. subtilis 3G18(pHB41) contained 6-HDNO polypeptide of the same size as authentic 6-HDNO (Fig. 2). The increased 6-HDNO activity measured in extracts from cells grown in the presence of nicotine compared to cells grown without this alkaloid (Table 1) was accompanied by a corresponding increase in 6-HDNO protein (Fig. 2, lanes 2 and 3).

In nicotine-induced $\boldsymbol{A}$. oxydans and also in $E$. coli HB101 harbouring pDB121 or the expression plasmid pDB222, a proportion of the 6-HDNO protein is in its apoenzyme form. Such apoenzyme can be flavinylated in vitro by incubation of soluble cell extracts with FAD and PEP (Nagursky et al., 1988). It is not understood why a fraction of the 6-HDNO protein exists as apoenzyme. The relative proportion of apoenzyme to holoenzyme is not related to the rate of protein synthesis, i.e. it does not result from a limiting supply of flavin. The formation of holoenzyme during the incubation can be monitored as an increase in enzyme activity and by incorporation of $\left[{ }^{14} \mathrm{C}\right] \mathrm{FAD}$ into the protein. A fraction of 6-HDNO expressed in $B$. subtilis 3 G18(pHB41) was similarly in the form of apoenzyme, since incubation of the cell extract with FAD and PEP resulted in increased 6-HDNO activity (Table 2).

$B$. subtilis, but not $E$. coli cells, take up riboflavin efficiently from the growth medium and use it for FMN and FAD synthesis (Cecchini et al., 1979). This property was exploited to confirm that the 6-HDNO synthesized from the $A$. oxydans gene in $B$. subtilis contains covalently bound flavin. Soluble cell extract was prepared from $B$. subtilis $3 \mathrm{G} 18(\mathrm{pHB} 41)$ grown in the presence of $\left[{ }^{14} \mathrm{C}\right]$ riboflavin. The cell extract was then incubated with $\left[{ }^{14} \mathrm{C}\right] \mathrm{FAD}$ and PEP to further increase 


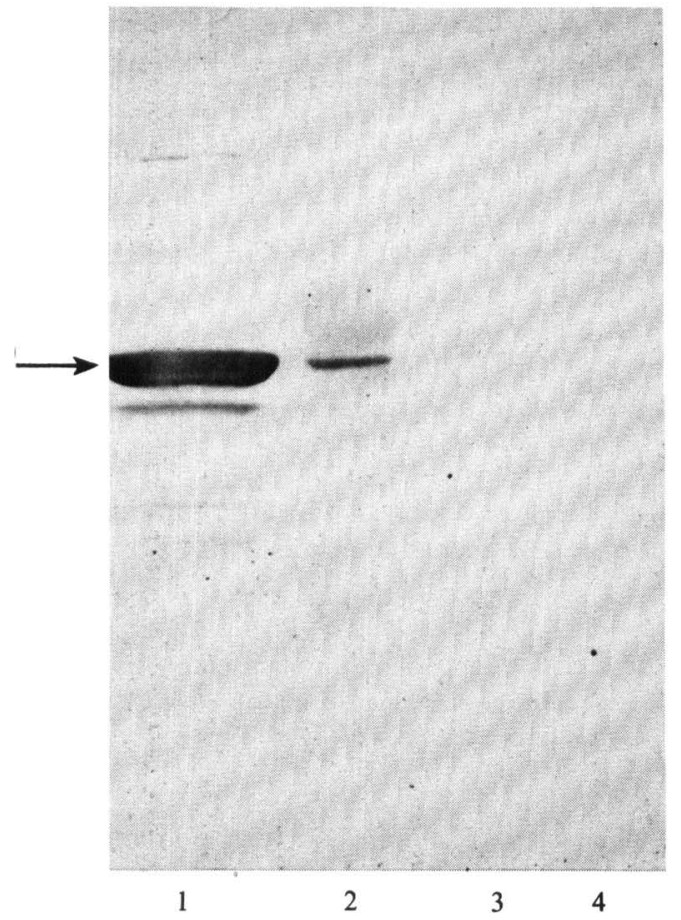

Fig. 2

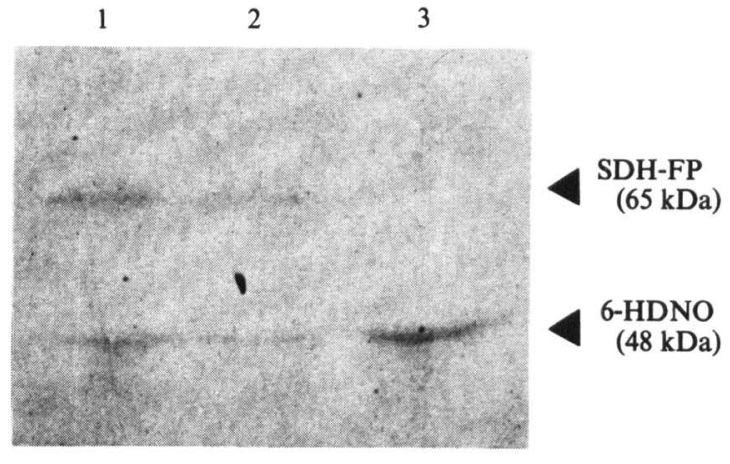

Fig. 3

Fig. 2. Analysis of 6-HDNO antigens by Western blotting. Soluble cell extracts, each containing $50 \mu \mathrm{g}$ protein, were run in SDS-PAGE $(10 \%, \mathrm{w} / \mathrm{v}$, acrylamide $)$, electroblotted to nitrocellulose membrane and stained immunochemically using 6-HDNO-specific antiserum from rabbit. Lane 1, $E$. coli HB101(pDB222); lane 2, B. subtilis 3G18(pHB41) grown with nicotine; lane 3, B. subtilis 3G18(pHB41) grown without nicotine; lane $4, B$. subtilis 3 G18(pSDP4) (negative control). The arrow indicates the position of $48 \mathrm{kDa} 6$-HDNO polypeptide. Smaller-sized antigens seen in lane 1 are proteolytic degradation products of 6-HDNO.

Fig. 3. Covalently bound flavin in cell extracts. An autoradiograph of a SDS-polyacrylamide $(10 \%$, $\mathrm{w} / \mathrm{v}$, acrylamide) gel is shown. Extract of $B$. subtilis $3 \mathrm{G} 18(\mathrm{pHB} 41)$ grown in the presence of DL-nicotine and $\left[{ }^{14} \mathrm{C}\right]$ riboflavin (lane 2) and then incubated in vitro with $\left[{ }^{14} \mathrm{C}\right] \mathrm{FAD}$ and PEP (lane 1). Extract of E. coli $\mathrm{HB} 101$ (pDB222) in vitro incubated with [ $\left.{ }^{14} \mathrm{C}\right] \mathrm{FAD}$ and PEP (lane 3). About $50 \mu \mathrm{g}$ of protein was loaded on each lane.

radioactive labelling. The extracts were finally subjected to SDS-PAGE. Only covalently bound flavin is retained on protein after electrophoresis in the presence of SDS (Hederstedt, 1983). An autoradiograph of the resulting gel is shown in Fig. 3. Two radioactive polypeptides can be seen. The $65 \mathrm{kDa}$ protein is the flavoprotein subunit of SDH. The $48 \mathrm{kDa}$ band corresponds to 6-HDNO. This band was not present on autoradiographs of gels containing similarly prepared extracts from $B$. subtilis not expressing 6-HDNO. We conclude that $A$. oxydans 6-HDNO is flavinylated in $B$. subtilis.

\section{CONCLUSION}

A. oxidans 6-HDNO seems different with regard to the mechanism of flavinylation, when compared to the flavoprotein subunits of SDH and fumarate reductase. The 6-HDNO protein can be flavinylated in different organisms and it can also be flavinylated in vitro in the presence of FAD and PEP (Brandsch \& Bichler, 1987; Nagursky et al., 1988). The flavoprotein of $B$. subtilis SDH, on the other hand, is not flavinylated in $E$. coli in vivo (Hederstedt et al., 1987) or in vitro even if $B$. subtilis extract is added (unpublished data). $E$. coli fumarate reductase could not be flavinylated when expressed in vitro in an $E$. coli coupled transcription-translation system 
(Cecchini et al., 1985). Furthermore, flavinylation of $B$. subtilis SDH is very sensitive to structural changes: amino acid substitutions in the flavoprotein far from the flavin-binding His residue can affect the attachment of flavin (Maguire et al., 1986). 6-HDNO apparently can be flavinylated despite gross changes in the polypeptide, such as deletions and fusions (Brandsch $e t$ $a l ., 1987 a$ ). FAD is bound to a His in the N-terminal part of the flavoprotein in 6-HDNO, SDH and fumarate reductase. The primary sequence around this His in 6-HDNO shows little similarity compared with those in SDH and fumarate reductase. In the flavoprotein of SDH and fumarate reductase, but not in 6-HDNO, the FAD-His residue is preceded by a sequence typical for nucleotide-binding proteins (Brandsch et al., 1987c). All these data together indicate that the mechanism for flavinylation of 6-HDNO is different from that of SDH and fumarate reductase. The flavinylation of the $A$. oxydans protein could be autocatalytic and mediated by universal cell factors, such as PEP.

Note added in proof. A mutation has been found in the -10 region of the $s d h$ promoter in pSDP4 used for construction of pHB41. The mutation, a $\mathrm{T}$ to $\mathrm{C}$ change at nucleotide position 163 , decreases expression about fourfold.

We thank Beate Krauss for expert technical assistance. This work was supported by a short term fellowship from EMBO to R. B. and by grants from the Swedish Natural Science Research Council, Emil och Wera Cornells Stiftelse and the Deutsche Forschungsgemeinschaft, Bonn-Bad Godesberg (SFB206).

\section{REFERENCES}

ARWERT, F. \& VENEMA, G. (1973). Transformation in Bacillus subtilis. Fate of newly introduced transforming DNA. Molecular and General Genetics 123, 185198.

Berger, S. L. \& Kimmel, A. R. (1987). Guide to molecular cloning techniques. Methods in Enzymo$\log y$ 152, 33-170.

BOYER, H. W. \& Roulland-Dussoix, D. (1969). A complementation analysis of the restriction and modification of DNA in Escherichia coli. Journal of Molecular Biology 41, 459-472.

BRANDSCH, R. \& BiChLER, V. (1985). In vivo and in vitro expression of the 6-hydroxy-D-nicotine oxidase gene of Arthrobacter oxidans, cloned into Escherichia coli, as an enzymatically active, covalently flavinylated polypeptide. FEBS Letters 192, 204-208.

BRANDSCH, R. \& BICHLER, V. (1986). Studies in vitro on the flavinylation of 6-hydroxy-D-nicotine oxidase. European Journal of Biochemistry 160, 285-289.

BRANDSCH, R. \& BICHLER, V. (1987). Covalent flavinylation of 6-hydroxy-D-nicotine oxidase involves an energy-requiring process. FEBS Letters 224, 121 124.

Brandsch, R., Faller, W. \& Schneider, K. (1986). Plasmid pAO1 of Arthrobacter oxidans encodes 6hydroxy-D-nicotine oxidase: cloning and expression of the gene in Escherichia coli. Molecular and General Genetics 202, 96-101.

BRANDSCh, R., BiChleR, V. \& NAGURSKY, H. (1987a). Covalent flavinylation of 6-hydroxy-D-nicotine oxidase analyzed by partial deletions of the gene. European Journal of Biochemistry 165, 559-564.

Brandsch, R., HinkKanen, A. E., Mauch, L., NAGURSKY, H. \& DECKER, K. (1987b). 6-Hydroxy-Dnicotine oxidase of Arthrobacter oxidans. Gene structure of the flavoenzyme and its relationship to 6-hydroxy-L-nicotine oxidase. European Journal of Biochemistry 167, 315-320.

Brandsch, R., Hinkkanen, A. E., Mauch, L., NAGURSKY, H. \& DeCKer, K. $(1987 c)$. The flavin- binding sites of 6-hydroxy-D- and 6-hydroxy-Lnicotine oxidases. In Flavins and Flavoproteins, pp. 747-750. Edited by D. E. Edmondson \& D. B. McCormick. New York: Walter de Gruyter.

BRÜHMÜlleR, M., MÖHLER, H. \& DECKER, K. (1972). Covalently bound flavin in 6-D-hydroxynicotine oxidase from Arthrobacter oxidans. Purification and properties of 6-D-hydroxynicotine oxidase. European Journal of Biochemistry 29, 143-151.

Cecchini, G., Perl, M., Lipsick, J., Singer, T. P. \& KeARnEY, E. B. (1979). Transport and binding of ribofiavin by Bacillus subtilis. Journal of Biological Chemistry 254, 7295-7301.

Cecchini, G., Kearney, E. B., Jones, H. \& Gunsalus, R. P. (1985). Studies on the attachment of covalent flavins to fumarate reductase from Escherichia coli. Federation Proceedings 44, 1766.

Cecchini, G., Ackrell, B. A. C., Whittiker, K., Blout, M. \& Gunsalus, R. P. (1988). Fumarate reductase containing non-covalently bound FAD. FASEB Journal 2, 354.

ColE, S. T. (1982). Nucleotide sequence coding for the flavoprotein subunit of the fumarate reductase of Escherichia coli. European Journal of Biochemistry 122, 479-484.

DECKeR, K. (1982). Biosynthesis of covalent flavoproteins. In Flavins and Flavoproteins, pp. 465-472. Edited by V. Massey \& C. H. Williams. Amsterdam: Elsevier North Holland.

DECKER, K. \& BLEEG, H. (1965). Induction and purification of stereospecific nicotine oxidizing enzymes. Biochimica et biophysica acta 105, 313-334.

DeCKer, K., Gries, F. A. \& BRÜHMÜlleR, M. (1961). Über den Abbau des Nicotins durch Bakterienenzyme. III. Stoffwechselstudien an Zellfreien Extrakten. Hoppe-Seyler's Zeitschrift für Physiologische Chemie 323, 249-263.

DoI, R. H. \& WANG, L.-F. (1986). Multiple procaryotic ribonucleic acid polymerase sigma factors. Microbiological Reviews 50, 227-243. 
Eberwein, H., Gries, F. A. \& Decker, K. (1961). Über den Abbau des Nicotins durch Bakterienenzyme. II. Isolierung und Charakteriserung eines nicotin-abbauenden Bodenbakteriums. Hoppe Seyler's Zeitschrift für Physiologische Chemie 323, 236-248.

Gloger, M. \& DeCKer, K. (1969). Zum Mechanismus der Inducktion nicotinabbauender Enzyme in Arth-

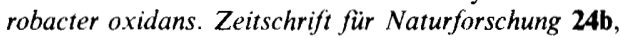
1016-1025.

Gryczan, T. J., Contente, S. \& Dubnau, D. (1978). Characterization of Staphylococcus aureus plasmids introduced by transformation into Bacillus subtilis. Journal of Bacteriology 134, 318-323.

Hager, P. W. \& Rabinowitz, J. C. (1985). Translational specificity in Bacillus subtilis. In The Molecular Biology of the Bacilli, vol 2, pp. 1-32. Edited by D. A. Dubnau. New York: Academic Press.

HeDERSTEDT, L. (1983). Succinate dehydrogenase mutants of Bacillus subtilis lacking covalently bound flavin in the flavoprotein subunit. European Journal of Biochemistry 132, 589-593.

Hederstedt, L., Bergman, T. \& JöRnVAll, H. (1987). Processing of Bacillus subtilis succinate dehydrogenase and cytochrome $b_{558}$ polypeptides. Lack of covalently bound flavin in the Bacillus enzyme expressed in Escherichia coli. FEBS Letters 213, 385390.

Ish-Horowicz, D. \& Burke, J. F. (1981). Rapid and efficient cosmid cloning. Nucleic Acids Research 9 , 2989-2998.

LAEMMLI, U. K. (1970). Cleavage of structural proteins during the assembly of the head of bacteriophage T4. Nature, London 227, 680-685.

Maguire, J. J., Magnusson, K. \& Hederstedt, L. (1986). Bacillus subtilis mutant succinate dehydrogenase lacking covalently bound flavin: identification of the primary defect and studies on the ironsulfur clusters in mutated and wildtype enzyme. Biochemistry 25, 5202-5208.

Melin, L., Magnusson, K. \& Rutberg, L. (1987). Identification of the promoter of the Bacillus subtilis sdh operon. Journal of Bacteriology 169, 3232-3236.

MöhleR, H., BRÜHMÜller, M. \& DeCKer, K. (1972). Covalently bound flavin in D-6-hydroxynicotine oxidase. Identification of the $8 \alpha-(N-3$-histidyl)-riboflavin linkage between FAD and the apoenzyme. European Journal of Biochemistry 29, 152-155.

NAGURSKY, H., BichleR, V. \& BRANDSCH, R. (1988). Phosphoenolpyruvate-dependent flavinylation of 6-hydroxy-D-nicotine oxidase. European Journal of Biochemistry 177, 319-325.

Phillips, M. K., Hederstedt, L., Hasnain, S., RutberG, L. \& GUest, J. R. (1987). Nucleotide sequence encoding the flavoprotein and iron-sulfur protein subunits of the Bacillus subtilis PY79 succinate dehydrogenase complex. Journal of Bacteriology 169, 864-873.

Salach, J., Walker, W. H., Singer, T. P., Ehrenberg, A., Hemmerich, P., Ghisla, S. \& HARTMANN, U. (1972). Studies on succinate dehydrogenase. Site of attachment of the covalently bound flavin to the peptide chain. European Journal of Biochemistry 26, 267-278.

SHAW, W. V. (1975). Chloramphenicol acetyltransferase from chloramphenicol resistant bacteria. Methods in Enzymology 43, 737-755.

Singer, T. P. \& McIntire, W. S. (1984). Covalent attachment of flavin to flavoproteins: occurrence, assay and synthesis. Methods in Enzymology 106, 369-378.

Timoco, I., Jr, Borer, P. N., Dengler, B., Levine, M. D., Uhlenbeck, O. C., Crothers, D. M. \& Gralla, J. (1973). Improved estimation of secondary structure in ribonucleic acids. Nature, London 246, 40-41.

Williams, D. M., Duvall, E. J. \& Lovett, P. S. (1981). Cloning restriction fragments that promote expression of a gene in Bacillus subtilis. Journal of Bacteriology 146, 1162-1165.

WoEse, C. R. (1987). Bacterial evolution. Microbiological Reviews 51, 221-271.

Wood, D., Darlison, M. G., Wilde, R. J. \& Guest, J. R. (1984). Nucleotide sequence encoding the flavoprotein and hydrophobic subunits of the succinate dehydrogenase of Escherichia coli. Biochemical Journal 222, 519-534. 